\title{
EFFECT OF FEEDING DIFFERENT DIETARY ENERGY LEVELS ON PRODUCTIVE AND PHYSIOLOGICAL PERFORMANCE OF BROILER CHICKS UNDER DIFFERENT HOUSING SYSTEMS
}

\author{
A.I. El-Faham ${ }^{1}$; Nematallah G.M. Ali ${ }^{1}$ and Raham M. Ali ${ }^{2}$ \\ ${ }^{1}$ Poult. Prod. Dept. of Agric., Ain Shams Univ., Egypt. \\ ${ }^{2}$ Animal and Poult. Prod. Dep., Fac. of Agric. and Natural Resources, Aswan Univ., Aswan, Egypt.
}

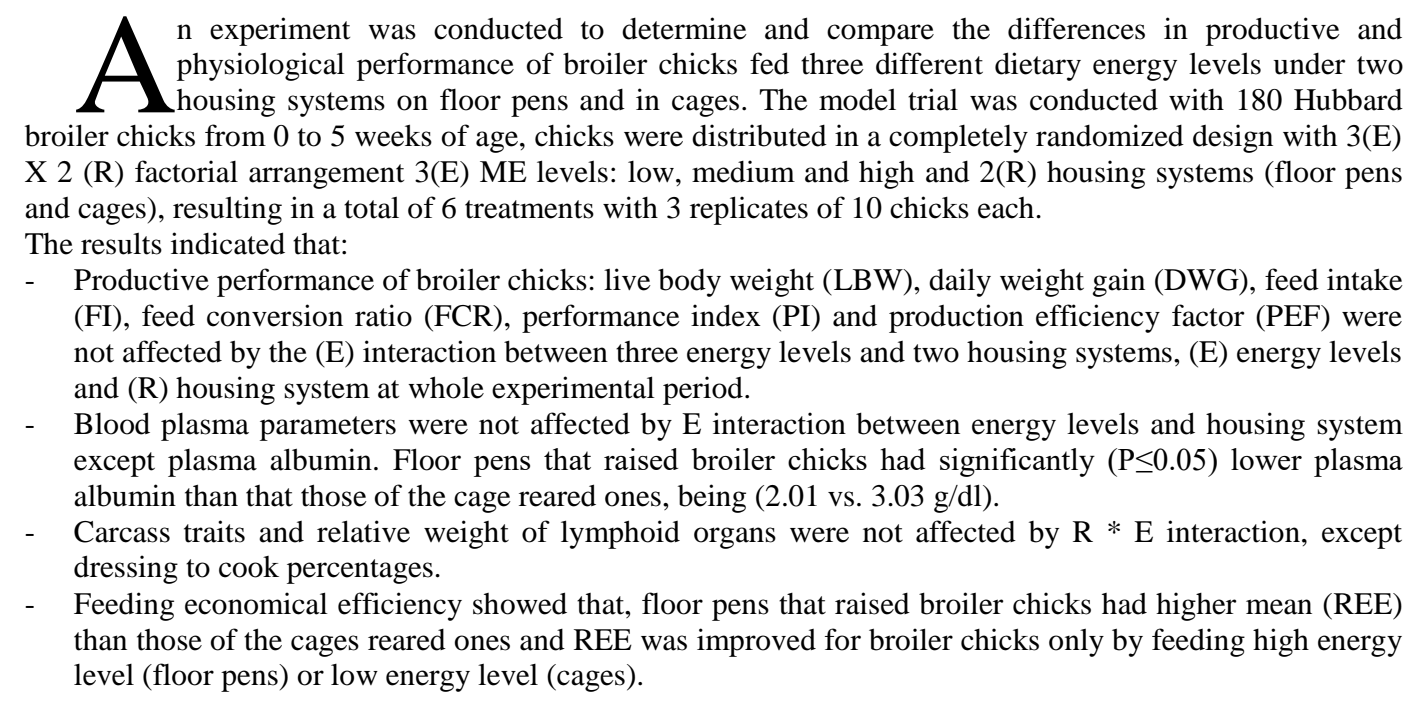

Keywords: Metabolizable energy, cages, floor pens and broiler chicks.

\section{INTRODUCTION}

There is growing trend worldwide to feed poultry diets containing only plant material or vegetable protein (VP) diets. The growth responses of broiler to VP diets are influenced by many factors, including energy level, diet composition, physical nature of the diet and level of anti-nutritive factors (Gatel, 1993; Dublecz, 2003; Cowieson and Bedford; 2009; Abdel-Hady 2012 and Hossain et al., 2015). Energy level in broiler diets is considered to be the most important nutrient required from the stand point of total cost and quality of broiler diets. As general rule, the birds consume feed to primarily meet their energy requirements. So, within limits, the energy content of the diet determines the quantity of feed consumed, including the quantity of protein, minerals and vitamins contained in that feed (Golian and Maurice, 1992 and Lesson et al., 1996).

Covering the metabolizable energy (ME) content of broiler diets reduce feed cost and allow for use of alternate feedstuffs. Some researches have found that reducing dietary ME effect on growth performance and weight gain were linearly decreased, whereas feed intake and feed conversion ratio were increased linearly (Sizenore and Siegel, 1993; Hidalgo et al., 2004 and Kamran et al., 2008).

Hidalgo et al. (2004) showed that progressive concentrations of dietary increased the growth of chicks but did not influence feed consumption, feed conversion ratio, or the incidence of mortality from placement until 17 day of age. In the some order, Sizemore and Siegel (1993) observed that lighter body weight when birds fed lower density- starter diets compared to those fed higher density diets at three weeks of post hatch. The feed conversion ratio was decreased significantly with elevated dietary energy. The lower feed conversion ratio were observed for birds receiving diets contained $>3000 \mathrm{Kcal} / \mathrm{kg}$. The 
differences among dietary treatments were more shown in grower period. Dietary energy levels appears to be the most important factor affecting feed and nutrients intakes (Hunton, 1995; Shaapan, 2004 and Ramadan, 2005). It is now-well documented that dietary composition and the ratios between macronutrients have a major effect on performance and body composition of chickens.

Dietary protein and energy levels for chickens have a major impact on chick performance and economic productively (Aggoor et al., 1997; Makled et al., 2001 and Salwa and Fawazy, 2003).

Some investigators concluded that broiler chicks fed on low protein or low energy diets showed significantly lower daily gain and insignificant better feed conversion than that those fed on control diet up to 7 weeks of age, but the effect of level of protein or energy on carcass traits had not significant (ElHindawy et al., 1997; Abd Elsamee, 2001 and Hassanien 2006).

On the other hand, managerial conditions such as care, feeding, number of birds per space area and sheltering provided for birds under different housing systems should be taken into consideration to get full advantage capacities of birds. Housing systems for broiler chicks, Japanese quails and laying hens have considerable effects on performance and production traits. (Andrews, 1978; Sharaf, 1996; Singh et al., 2009 and Enaiat et al., 2009).

In spite of, there are a lot of researches on the influences of housing systems on chicken performance. However, the results of these works are contradictory. Therefore, the present work was undertaken to evaluate and compare the differences in productive and physiological performance of broiler chicks fed different dietary energy levels under two housing systems (Cages and Floor pens).

\section{MATERIALS AND METHODS}

This study was carried out in the Poultry experimental unit, Agriculture Experiment and Research Station at Shalakan, Faculty of Agriculture, Ain Shams University, in order to investigate the effects of two housing systems (Cages and floor pens) for broiler chicks fed all-plant protein diets with three different dietary metabolizable energy on the growth performance, some blood components, carcass characteristics and economic efficiency.

A total number of 180 Hubbard broiler chicks, one day old were distributed into two main groups (90 chicks each) according to initial chick weight and randomly assigned into pens or cages with 10 broiler chicks per $1.0 \mathrm{~m}^{2}\left(100 \times 100 \mathrm{~cm}\right.$ per cage or floor pen) which resulted in $1.0 \mathrm{~m}^{2}$ per individual chicks. Hubbard broiler chicks rearing under the same light and vaccination program, water and feed adlibtum.

Each of main group was randomly divided into three subgroups (30 chicks each) and subgroups contained three replicates (10 chicks each). Chicks in the first sub group were fed on starter $(2912 \mathrm{kcal}$ $\mathrm{ME} / \mathrm{kg}$ ) and grower $(3032 \mathrm{kcal} \mathrm{ME} / \mathrm{kg}$ ) diets which formulated to meet the nutrient requirements of broiler chicks (control diet).

NRC (1994) showed that chicks in the second and third sub group were fed on starter and grower diets which formulated to have about 100 and $200 \mathrm{kcal} \mathrm{ME} / \mathrm{kg}$ diet high than the control diets, respectively. All diets were adjusted to be iso-nitrognous of about $23 \%$ and $21 \% \mathrm{CP}$ in starter and grower diets, respectively and starter diets were offered from 0 to 3 weeks of age while, grower diets were fed from 4 to 5 weeks of age.

The composition and calculated chemical analysis of the different experimental starter and grower diets are shown in Table (1).

The performance parameters included body weight and feed intake which were determined at the end of starter (3 weeks of age) and grower ( 5 weeks of age) periods and taken daily body weight gain (DWG), daily feed intake (DFI), feed conversion ratios (FCR), performance index (PI) and production efficiency factor (PEF) were calculated. At 5 weeks of age (end of the experiment period), three birds from each treatments representing the average body weight of each treatment were slaughtered. After slaughtering and complete bleeding, the birds were scalded and feathers were removed. Carcass was eviscerated then, feet, head, neck, shanks and giblets were removed then the carcasses were weighted.

Individual blood samples were collected in dry clean centrifuge tubes from the slaughtered birds and plasma was separated by centrifugation at 3000 (prm) for 15 minutes and assigned for subsequent determination. Plasma samples were stored at $\left(-20^{\circ} \mathrm{C}\right)$ in a deep freezer until the time of chemical determination. Values of total protein, albumin, total cholesterol and triglycerides were estimated by using commercial diagnosing kits (produced by Biodignostic Company, Egypt). The globulin values were obtained by subtracting the values of albumin from the corresponding values of total protein.

Finally, the economical evaluation and production cost analysis was carried out for all treatments in attempt to investigate the effect of housing system and dietary metabolizable energy levels on feeding costs (Bayoumi, 1980). 
Data were subjected to two-way analysis of variance in a (3 x 2) factorial arrangement using dietary energy level and housing system as main effects. SAS general linear model software (SAS, 2000) was used. Duncan's multiple range tests separated means (Duncan, 1955). The relationship between traits was assessed by correlation coefficient.

\section{RESULTS AND DISCUSSION}

\section{Productive performance:}

\section{Live body weight and daily weight gain:}

The live body weight (LBW) and daily weight gain (DWG) of broiler as affected by dietary treatments and housing system are illustrated in Table (2). It is worth to note that the chicks fed (Low) energy diet during starting period (0-3 wks.) reflected the highest insignificant results in both live body weight and daily weight gain compared to those fed diets containing (medium or high) of energy, being (680.22 $\mathrm{g}$ versus 668.44 and $645.19 \mathrm{~g})$ and (30.16 versus 29.59 and $28.49 \mathrm{~g}$ ) respectively, the differences were statistically not significant. These findings are in agreement with those obtained by Sizemore and Siegel (1993) who observed lighter body weight when broilers fed lower density starter diets compared to those fed higher density diets at 3 weeks of post hatch. In the same order, Hunton (1995) found that nutrients intake can be influenced by different levels of energy in diet, therefore, deficiency of nutrients may occur in broiler by increasing the energy content in diet.

During the growing and whole studied periods (4-5 and 0-5 wks.), chicks fed (high) dietary energy level gave slightly increased body weight and daily body weight gain compared to those fed diets containing lower level of energy (low and medium). In addition, chicks fed (Medium) dietary energy levels showed the highest reduction in body weight being (7.5\%), compared to those fed diets containing higher levels (1650.76 versus $1784.51 \mathrm{~g}$ ). Daily body weight gain (DWG) showed the same trend since, feeding diet containing (High) energy level reflected the highest insignificant (49.65 g) (DWG) followed by those fed (low), while chicks fed (Medium) energy level had the lowest DWG (being 47.19 and $44.81 \mathrm{~g}$, respectively), however, the differences failed to be insignificant. Similar observation was reported by Kamran et al. (2008), who stated that weight gain was linearly decreased whereas feed intake and feed conversion ratio were increased as dietary energy and protein decreased during experimental periods. Increasing dietary metabolizable energy significantly increased the body weight gain (Lesson, 1996 and Zaman et al., 2008).

The obtained data showed that there were insignificant differences in (LBW and DWG) among housing system during the studied period (0-5 wks.). Cage that raised broiler chicks had highest insignificantly results. However, body weight increased by $2.1 \%$ (1729.07 vs. $1693.48 \mathrm{~g}$ ) compared with those of the floor pen ones and DWG showed similar trend (48.06 vs. $46.37 \mathrm{~g}$ ). Besides, the differences between the two housing systems were insignificant. These findings are in contrast with the results obtained by Andrews (1978) in broiler chicks and Sharaf (1996) in quail, they concluded that birds reared on floor were significantly heavier $(\mathrm{P}<0.05)$ than the birds that reared in cages.

\section{Feed intake and feed conversion:}

The obtained data showed that there were insignificant differences in feed intake and feed conversion among treatments and housing systems during the studied period (0-5 wks.).

Data in Table (3) indicated that daily feed intake per birds $(\mathrm{g} / \mathrm{d})$ was insignificantly decreased by feeding medium dietary energy diets compared with those fed control diets (low). The decrease in feed consumption was more produced during growing periods (4-5 wks.) being 5\%, while it was $4 \%$ during the starting period (0-3 wks.).

The corresponding figures were 75.56 versus $79.28(\mathrm{~g} / \mathrm{d})$ during overall period, without any significant differences. This might be due to the fact that birds meet their energy requirements by increasing feed consumption, according to Scott et al. (1982), and Lesson et al. (1996). Increasing metabolizable energy by 100 or $200 \mathrm{kcal} / \mathrm{kg}$ in experimental diets, respectively, showed no negative effect on daily feed consumption and the differences between treatments failed to be insignificant (Table 3). Feed conversion ratio (FCR) showed the same trend since birds fed control diet (low) were less efficient in converting their food into body weight gain compared with those fed (medium or high) energy diets. The best FCR was detected for the chicks fed diets with high energy levels (1.63). On the other hand, the worst FCR were found in chicks fed control diets (1.69) and the differences between treatments failed to the insignificant.

The obtained results are in agreement with those reported by Sizemore and Siegel (1993), in which they concluded that feed conversion ratio was decreased significantly with elevated dietary energy and 
the lower FCR were observed for chicks receiving diets contained $>3000 \mathrm{kcal} / \mathrm{kg}$. Similar findings were reported that the growth rate and FCR of broiler chickens were improved by increasing the dietary energy concentration (Kamran et al., 2008). In addition, Hidalgo et al. (2004) noted that progressive concentrations of dietary energy increasing the growth of chicks but did not influence feed consumption, FRC or the incidence of mortality.

On the other hand, data in Table (3) indicated that cages that raised broiler chicks had significantly $(\mathrm{P}<0.01)$ increased daily feed consumption per chicks $(\mathrm{g} / \mathrm{d})$ compared with those that raised in the floor pen during starting period (0-3 wks.). However, during the growing and whole experimental periods cages that raised broiler chicks showed the higher insignificant figures of daily feed consumption. Feed conversion ratio showed the same trend since floor pen raised broiler chicks had significantly $(\mathrm{P}<0.01)$ better feed conversion ratio compared with those of cage reared ones during starting period and insignificant better during growing and whole experimental periods. The corresponding values were ( 81.03 vs. $76.37 \mathrm{~g}$ ) and 1.64 vs. 1.69) for daily feed consumption and feed conversion ratio, respectively during experimental period (0-5 wks.).

These findings are in contrast with the results obtained by Sharaf (1996), who concluded that cage raised quails used the feed more efficient than those the floor quails.

\section{Performance index (PI) and productive efficiency factors (PEF):}

Insignificant differences were observed in (PI) and (PEF) between experimental treatments due to varing dietary metabolizable energy or housing systems during all experimental period (Table 4). Moreover, PI and PEF values were insignificantly increased by increasing ME level in the diets during all experimental period. Values of PI and PEF were insignificant increased by 3.0 and $17.0 \%$ as a result of feeding (high), ME diets as compared to those fed (low and medium) ME diets, respectively at (0-5) wks. of age. On the other hand, floor pen raised broiler chicks had insignificant higher PI and PEF values than those of the cage reared ones. The corresponding values of PI and PEF were (101.47 vs. 95.90) and (289.92 vs. 274.02), respectively without any significant differences. These results are in agreement with those reported by Kout El-Kloub et al. (2010) who reported that PIU values were insignificantly decreased by increasing both ME and CP levels in Domyati duckling diets during 0-12 wks. of age. These findings are in contrast with the results obtained by Awad et al (2014), who showed that significant differences were observed in PI between experimental treatments due to varying ME, CP levels and duckling sex during all experimental periods (2-20 wks.).

\section{Blood plasma parameters:}

Table (5) shows values of some blood plasma parameters at 5 weeks of age. Generally, different dietary treatments and rearing had no significant effects on all measured parameters except values of albumin for birds that reared on floor or cages. Although values of blood plasma parameters had no significant differences, but numerically there were some variations had showed, for example, the birds that fed on the high energy showed the lowest values for total protein and albumin. On the other hand, the birds that fed on medium energy showed the highest values for globulin and that means this treatment had improved immunity compared to other treatments.

These results in agreement with Mona and Osman (2008), who indicated that, insignificant effects of high energy diets on blood constituents except total protein and globulin had significant improvement.

Regarding to lipid metabolism, results showed that the birds that fed on medium energy and reared in cages had lowest values of cholesterol in plasma compared to other treatments, but birds that fed on high energy showed the lowest values of triglycerides in plasma, but these birds also reared in cages. That means, the birds that reared in cages and fed on the medium and high energy showed the lowest values of cholesterol and triglycerides. It may be these treatments and rearing decreased the metabolism of lipids in bird's body. The cholesterol lowering effect may also be due to deconjugation of bile salts, which are less absorbed in the gastrointestinal tract. This results in huge fecal excretion of bile acids which in turn lowers cholesterol in the body pool, as cholesterol constitutes the precursor of bile salts. Also, products of bacteria fermentation, especially short chain fatty acids, may inhibit cholesterol synthesis in the liver and mobilize plasma cholesterol to the liver (Sturkie, 1986). These results disagree with Elmansy (2006) who reported that the higher level of energy (3200 kcal ME/k diet) induced a higher level of triglyceride and cholesterol. Also, Hasanein (1995) found that as the dietary energy levels increased from 2600, 2800 to $3000 \mathrm{kcal} / \mathrm{ME} / \mathrm{kg}$ of diet resulted in increases of triglycerides and cholesterol in blood of quail.

\section{Carcass characteristics:}

Table (6) shows the effect of different dietary treatments on carcass characteristics for the chicks slaughtered at the end of 5 wks. of age. No significant differences were observed by feeding different ME 
levels in the diet in all carcass traits (expressed as percentage of live body weight). The corresponding values for dressing percentages ranged between 67.49 and $68.91 \%$, while ready to cook (Hot carcass weight + giblets) percentages ranged between 71.58 and $72.53 \%$ and giblets percentages ranged between 4.40 and $4.66 \%$. On the other hand, the birds fed medium and high levels of energy gave the highest figures (being the same figure $72.53 \%$, respectively), for ready to cook compared with the birds fed control diet (low) being $71.58 \%$.

In the same order, abdominal fat percentages were insignificant increased by increasing ME levels, the highest values were recorded with chickens fed high levels of energy $(0.88 \%)$ compared to medium $(0.80 \%)$ or low $(0.73 \%)$ levels, without any significant differences.

Means relative weights of primary (bursa and thymus) and secondary (spleen) lymphoid organs are presented in Table (3). Insignificant differences were noted among the different experimental treatments for the relative weights of lymphoid organs. However, with respect to the bursa and spleen, the relative weights of broiler chickens fed low energy diets (control) were insignificantly higher than those fed diets containing (medium or high) of energy, being ( 0.18 versus 0.15 and $0.16 \%)$ and $(0.09$ versus 0.07 and $0.08)$ respectively.

The response to housing systems (floor pen versus cage) on carcass characteristics showed significant differences in dressing \% and ready to cook \% in the relation to housing systems. In general, the highest figures of carcass characteristics were seen when chicks reared on floor pen and the corresponding values were $(68.44$ vs. $66.44 \%)$ and $(73.05$ vs. $71.1 \mathrm{P} \%)$ for dressing and ready to cook $\%$, respectively with significances differences between the two housing system. In the same order, abdominal fat $\%$ and giblets $\%$ figures showed the same trend, in which chicks reared on floor pen reflected the highest figures and the corresponding figures being ( 0.9 vs. $0.7 \%)$ and (4.61 vs. $4.52 \%)$ respectively, without any significant differences. The corresponding values of relative weights of lymphoid organs were $(0.07$ vs. $0.09 \%)$, $(0.18$ vs. $0.14 \%)$ and $(0.16$ vs. $0.17 \%)$ for spleen, thymus and bursa $\%$, respectively and the differences were insignificant.

These findings are in contrast with the results obtained by Kout Elkloub et al. (2010) who concluded that abdominal fat percentage was significantly increased by increasing ME levels of Domyati duckling diets during growth period. Also, abdominal or carcass fat was significant increased by using ME in diets above $2700 \mathrm{kcal} / \mathrm{kg}$ (Ghaffari et al., 2007; Ghazalah et al., 2008 Zhuye et al., 2009). In addition, Albuqueque et al. (2003) reported that carcass and edible parts yields were significantly lowered of broiler fed low-ME than birds high-ME at day 42 of age.

\section{Economical evaluation:}

Data for economical evaluation are summarized in Table (7). Calculation of feeding economical efficiency were carried according to the prices of feed ingredients, price of one-kilogram live body weight, which was 13.0 L.E. at the end of experimental period, live body weight prevailing during the experimental time as listed in Table (7). The average cost/ton of final experimental diets (starter and grower) are shown in Table (1). It was clear that reducing dietary metabolizable energy [high, medium and low (control)] relatively reduced the cost/ton final diets. The cost reduction in both starter and grower diets were more pronounced in control diets (low, ME) compared to medium and high ME in diets. This difference could be explained on the basis that it was necessary to increase the level of the expensive stabilized fat (soybean oil) in diets in order to increase experimental diet caloric.

As shown in Table (7), data representing feed cost, it is generally observed that birds fed (high energy) diets have been costly when compared to those fed (medium or low) energy diets, in addition it is interesting to state that under the condition of the present study, within the same housing system (floor pen or cage), broiler chicks fed medium dietary energy reflected the lowest relative economic efficiency REE, compared with that fed other treatments (low or high dietary energy) and the corresponding values were 96.20 and 89.93 , respectively.

Moreover, feeding diets containing (high energy level-floor pen or low energy level- cage) gave the highest REE and the corresponding values were 101.43 and 102.86 , respectively.

On the other hand, floor pen raised broiler chicks had higher mean (REE) than those of the cage reared ones (99.21 vs. 96.98). Similar observation was reported by Abd El-Hady (2012), who stated that lowering metabolizable energy ( $100 \mathrm{kcal} / \mathrm{kg}$ diet $)$ decreased economic efficiency by $8 \%$ while in lowering (200 kcal / kg diet) economic efficiency lower by $4 \%$ than normal metabolizable energy diets.

\section{Interaction between housing systems and dietary energy levels (RXE):}

Generally in most cases, the interaction between dietary treatments and housing systems (Rx E) for studied criteria were insignificant on productive performance and economic efficiency (Tables 2, 3, 4, 5 and 6). 


\section{Health condition and mortality rate:}

Using different levels of metabolizable energy (E) or housing systems (R) have not negative response on health condition, fatty liver syndrome and mortality rate. Under the condition of the present study all chickens appeared healthy and the total mortality rate was $2.77 \%$ (5 chickens) during the total experimental period (0-5 wks.), without any clear differences among dietary treatments $(\mathrm{E})$, housing systems (R) and interaction between ( $\mathrm{R} \times \mathrm{E}$ ). Hence, it seems that neither levels of metabolizable energy nor housing systems influenced health conditions and mortality rate.

\section{CONCLUSION}

It could be concluded that, based on the described conditions under which this experimental was conducted, productive performance and blood plasma parameters of Hubbard broiler chicks were not affected by different dietary energy and housing system. Floor pens that raised broiler chicks had higher significantly of dressing and ready to cook percentages and higher mean than those of the cages reared ones and diets contained high or low $\mathrm{ME} / \mathrm{kg}$ were utilized more by the broiler chick raised in floor pens or on cages, respectively.

\section{REFERENCES}

Abd El-Hady, A.Y.M. (2012). Effect of enzyme preparations on apparent metabolizable of broiler diets. Ph.D. Thesis, Fac. of Agric. Ain Shams Univ. , Egypt.

Abd El-Samee, M.O. (2001). Broiler performance as effected by crude protein, lysine and a probiotic, Egypt. Poult. Sci. 21: 943-962.

Agoor, F.A.M.; N.M. El-Naggar; A.Z. Mehrez; Y.A.Attia and E.M.A. Qota (1997). Effect of different dietary protein and energy levels during roaster period on: 1 . Performance and economical evaluation of broiler chicks. Egypt. Poult. Sci., 17:81-105.

Albuquerque, R.; D.E. Faria; O.M. Junqueira; D. Salvador; F.D.E. Faria and M.F. Rizzo (2003). Effects of energy level in finisher diets and slaughter age on the performance and carcass yield in broiler chickens. Brazilian J. Poult. Sci., 5:99-104.

Andrews, L.D. (1978). Performance of broiler reared on rubber and plastic mats in a cage system and on litter in a floor system. Poult. Sci., 57: 1493-1498.

Awad, A.L.; Kout El Kloub; M. El-Moustafa; A.I.A. Ghonim and Nehad, A. Ramadan (2014). Comparative study for different levels of energy and protein in Sudani ducklings diet during growth period. Egypt. Poult. Sci., 34:537-560.

Bayoumi, S.B. (1980). Effect of different ration on egg production of breeding hens. M.Sc. Thesis, Fac. Agri., Kafr El-Sheikh, Tanta Univ., Egypt.

Cowieson, A.J. and M. Bedford (2009). The effect of phytase and carbohydrase on ileal amino acid digestibility in monogastric diets: Complimentary mode of action? World's Poult. Sci., 65:609-624.

Dublecz, K. (2003). Poultry nutrient without animal protein sources. Allattenyesztes es Takermanyozas, 52:479-489.

Duncan, D.B. (1955). Multiple range and multiple F. tests. Biometrics, 11: 1-42.

El-Hindawy, M.M.; A.I. Abd El-Ghani; M.I. Tawfeek; A.A. Habbeb and M.M. Shehata (1997). Effect of dietary energy and sulphur amino acids levels on growth performance, carcass traits and blood constituent of broiler chicks. Egypt. Poult. Sci., 17:65-80.

Elmansy, M.M. (2006). Assessment of the effect of L-carnitine supplementation to the diet with different dietary energy levels on broiler performance. M.Sc. Thesis, Fac. of Agric., Tanta Univ., Egypt.

Emmert, J. (2000). Efficacy of phase feeding in broilers. Proceeding, California Animal Nutrition Conference. Fresno California, USA.

Enaiat, M.M. El-Anwer; A.Salem Amina; M. Abou-Eitta; Eman and A.H.A. Al-Kotait (2009). A comparative study between two local strains under cage and floor housing system. Egypt. Poult. Sci., 29:439-464.

Gatel, F. (1993). Protein quality of legume seeds for non- ruminant animals: a literature review. Animal Feed Sci. and Technology, 45:317-348. 
Ghaffari, M.; M. Shivazad; M. Zaghari and R. Taherkhani (2007). Effects of different levels of metabolizable energy and formulation of diet based on digestible and total amino acid requirements on performance of male broiler. Int. J. Poult. Sci., 6:276-279.

Ghazalah, A.A.; M.O. Abd-Elsamee and A.M. Ali (2008). Influence of dietary energy and poultry fat on the response of broiler chicks to heat therm. Inter. J. Poult. Sci., 7:355-359.

Golian, A. and D.V. Maurice (1992). Dietary poultry fat and gastrointestinal transit time of feed and fat utilization in broiler chickens. Poult. Sci., 71:1357-1363.

Hasanein, M.S.M. (1995). Effect of energy source and level on performance of production and reproduction of Japanese quail. M.Sc., Thesis, Dept. of Anim. Prod., Fac. of Agric., Al-Azhar Univ., Egypt.

Hassanein, H.H. (2006). Effect of initial chick body weight and diet on the growth performance of broiler chicks. Egypt. Poult. Sci., 26:1305-1320.

Hidalgo, M.A.; W.A. Dozier III, A.J.; A.J. Davis and R.W. Gordon (2004). Live performance and meat yield responses to progress sive concentrations of dietary energy maintained at a constant metabolizable energy - to - crude protein ratio. J. Appl. Poult Res., 13:319-327.

Hossain, M.A.; M.M. Bhuiyan and P.A. IJI. (2015). Nutritive value of vegetable protein diets for broiler chickens and selection of diets containing different vegetable or animals protein. World's Poult. Sci. J., 71:15-25.

Hunton, H. (1995). Poultry production, Ontario, Canada, pp 53-118.

Kamran, Z.; M. Sarwar; M. Nisa; M.A. Nadeem; S. Mahmood; M.E. Babars and S. Ahmed (2008). Effect of low protein diets having constant energy-to-protein ratio on performance and carcass characteristics of broiler chickens from one to thirty-five days of age. Poult. Sci., 87 3:468-474.

Kout Elkloub, M. El-Moustafa; A.L. Awad and A.I.A. Ghonim (2010). Response of Domyati ducklings to diets containing different levels of metabolizable energy and crude protein: 1-During growth period. Egypt Poult. Sci., 30:535-564.

Lesson, S.; L. Caston and J.D. Summers (1996). Broiler response to dietary energy. Poult. Sci., 75:529535.

Makled, M.N.; El-Deeb; M.A. and N.H. Abdeallah, (2001). Effect of protein levels, energy level and season on performance of growing indigenous naked neck (Sharkasi) chickens. Egypt. Poult. Sci., 21:27-52.

Mona, S. Ragab and A.M.R. Osman (2008). Effect of feeding high dietary energy levels on productive performance of broiler chicks during the finisher period. Egypt. Poult. Sci., (28) (III):799-814.

North, M.O. (1981). Commercial chicken. Production Annual, $2^{\text {nd }}$ Edition, Av., Publishing Company I.N.C., West Post. Connecticut, USA.

NRC (1994). Nutrient Requirements of Poultry, $9^{\text {th }}$ revised edn. National Academy Press, Washington, DC.

Ramadan, Nehad A. (2005). Broiler performance as affected by dietary energy source and level. Ph.D. Thesis, Fac. Agric. Cairo Univ., Egypt.

SAS (2000). SAS/stat User's Guide: SAS Institute, Inc., Cary, Nc, USA.

Salwa, B. Abd El-Hady and F.A. Abd El-Ghany (2003). The effect of genotype dietary protein level and their interaction on chicken performance of two local strains. Egypt. Poult. Sci., 23:153-167.

Scott, M.L.; M.C. Nesheim and R.J. Yong (1982). Nutrition of the chicken, $3^{\text {rd }}$ ed M.L. Scott and associates, Ithaca, NY.

Shaapan, M.H.M. (2004). Response of broiler performance to dietary microbial phytase, energy levels, amino acids and phosphorus sources. Ph.D. Fac. Agric. Cairo Univ., Egypt.

Sharaf, M.M. (1996) Cage versus floor rearing of Japanese quails as affected by sex, age and bird density. Egypt. Poult. Sci., 16:725-738.

Singh, R.; K.M. Cheng and F.G. Silversides (2009). Production performance an egg quality of four strains of laying hens kept in conventional cages and floor pens. Poult. Sci., 88:256-264.

Sizemore, F.G. and H.S. Siegel (1993). Growth, feed conversion and carcass composition in females of four broiler crosses fed starter diets with different energy levels and energy to protein ratios. Poult. Sci., 72:2216-2228.

Sturkie, P. (1986). Avian physiology $5^{\text {th }}$ Ed. Academic Press SAV Dieage, California, U.S.A.

Zaman, Q.U.; T. Mushtaq; H. Nawaza, M.A. Mirza; S. Mahmood; T. Ahmed; M.E. Babar and M.M.H. Mushtaq (2008). Effect varying dietary energy and protein on broiler performance in hot climate. Anim. Feed Sci. Technol., 146:302-312.

Zhuye, N.; S. Jingsong; L. Fuzhu; W. Xianhui; G. Chunqi and Y. Likai (2009). Effects of dietary energy and protein on growth performance and carcass quality of broilers during starter phase. Inter. J. Poult. Sci., 8:508-511. 
Egyptian J. Nutrition and Feeds (2015)

Table (1). Feed ingredients and chemical analyses of experimental diets.

\begin{tabular}{|c|c|c|c|c|c|c|}
\hline \multirow{3}{*}{ Ingredients } & \multicolumn{6}{|c|}{ Dietary Treatments - Starter (0-21 days) } \\
\hline & \multicolumn{3}{|c|}{ On floor pens } & \multicolumn{3}{|c|}{ In Cages } \\
\hline & 1 & 2 & 3 & 4 & 5 & 6 \\
\hline Yellow Corn & 55.25 & 53.39 & 51.55 & 55.25 & 53.39 & 51.55 \\
\hline Soybean Meal $44 \%$ & 33.15 & 33.51 & 33.85 & 33.15 & 33.51 & 33.85 \\
\hline Corn Gluten $60 \%$ & 6.00 & 6.00 & 6.00 & 6.00 & 6.00 & 6.00 \\
\hline Soybean Oil & 1.00 & 2.50 & 4.00 & 1.00 & 2.50 & 4.00 \\
\hline Ca Carbonate & 1.60 & 1.60 & 1.60 & 1.60 & 1.60 & 1.60 \\
\hline Mono $\mathrm{Ca} \mathrm{Ph}$ & 1.80 & 1.80 & 1.80 & 1.80 & 1.80 & 1.80 \\
\hline LYS & 0.30 & 0.30 & 0.30 & 0.30 & 0.30 & 0.30 \\
\hline DL-METH & 0.30 & 0.30 & 0.30 & 0.30 & 0.30 & 0.30 \\
\hline Salt $(\mathrm{NaCl})$ & 0.30 & 0.30 & 0.30 & 0.30 & 0.30 & 0.30 \\
\hline Premix & 0.30 & 0.30 & 0.30 & 0.30 & 0.30 & 0.30 \\
\hline Total & 100 & 100 & 100 & 100 & 100 & 100 \\
\hline \multicolumn{7}{|c|}{ Chemical Analysis (Calculated) } \\
\hline $\mathrm{CP} \%$ & 23.00 & 23.00 & 23.00 & 23.00 & 23.00 & 23.00 \\
\hline $\mathrm{ME} \mathrm{Kcal} / \mathrm{Kg} \operatorname{diet}$ & 2912 & 3006 & 3100 & 2912 & 3006 & 3100 \\
\hline $\mathrm{Ca} \%$ & 1.00 & 1.01 & 1.01 & 1.00 & 1.01 & 1.01 \\
\hline $\mathrm{AP} \%$ & 0.50 & 0.50 & 0.50 & 0.50 & 0.50 & 0.50 \\
\hline LYS & 1.40 & 1.40 & 1.40 & 1.40 & 1.40 & 1.40 \\
\hline METH \& CYS & 1.07 & 1.07 & 1.07 & 1.07 & 1.07 & 1.07 \\
\hline \multirow[t]{2}{*}{ Price/ Ton (L.E.) } & 3568 & 3675 & 3781 & 3568 & 3675 & 3781 \\
\hline & \multicolumn{6}{|c|}{ Dietary Treatments - Grower (22-35 days) } \\
\hline \multirow{2}{*}{ Ingredients } & \multicolumn{3}{|c|}{ On Litter } & \multicolumn{3}{|c|}{ In Cages } \\
\hline & 1 & 2 & 3 & 4 & 5 & 6 \\
\hline Yellow Corn & 59.66 & 57.78 & 55.94 & 59.66 & 57.78 & 55.94 \\
\hline Soybean Meal 44\% & 29.15 & 29.53 & 29.87 & 29.15 & 29.53 & 29.87 \\
\hline Corn Gluten $60 \%$ & 5.00 & 5.00 & 5.00 & 5.00 & 5.00 & 5.00 \\
\hline Soybean Oil & 2.00 & 3.50 & 5.00 & 2.00 & 3.50 & 5.00 \\
\hline Ca Carbonate & 1.45 & 1.45 & 1.45 & 1.45 & 1.45 & 1.45 \\
\hline Mono $\mathrm{Ca} \mathrm{Ph}$ & 1.60 & 1.60 & 1.60 & 1.60 & 1.60 & 1.60 \\
\hline LYS & 0.27 & 0.27 & 0.27 & 0.27 & 0.27 & 0.27 \\
\hline DL-METH & 0.27 & 0.27 & 0.27 & 0.27 & 0.27 & 0.27 \\
\hline Salt $(\mathrm{NaCl})$ & 0.30 & 0.30 & 0.30 & 0.30 & 0.30 & 0.30 \\
\hline Premix & 0.30 & 0.30 & 0.30 & 0.30 & 0.30 & 0.30 \\
\hline Total & 100 & 100 & 100 & 100 & 100 & 100 \\
\hline \multicolumn{7}{|c|}{ Chemical Analysis (Calculated) } \\
\hline $\mathrm{CP} \%$ & 21.00 & 21.00 & 21.00 & 21.00 & 21.00 & 21.00 \\
\hline $\mathrm{ME} \mathrm{Kcal/Kg} \mathrm{diet}$ & 3032 & 3126 & 3220 & 3032 & 3126 & 3220 \\
\hline $\mathrm{Ca} \%$ & 0.90 & 0.91 & 0.91 & 0.90 & 0.91 & 0.91 \\
\hline $\mathrm{AP} \%$ & 0.45 & 0.45 & 0.45 & 0.45 & 0.45 & 0.45 \\
\hline LYS & 1.26 & 1.26 & 1.27 & 1.26 & 1.26 & 1.27 \\
\hline METH \& CYS & 0.98 & 0.98 & 0.98 & 0.98 & 0.98 & 0.98 \\
\hline Price/ Ton (L.E.) & 3446 & 3553 & 3659 & 3446 & 3553 & 3659 \\
\hline
\end{tabular}

MCP: mono-calcium phosphate, MHA: methionine hydroxy-analogue, NPP: non-phytate phosphorus.

The premix contains: Vitamins: A: 12000000 IU; Vit. D3 2000000 IU; E: 10000 mg; K3: 2000 mg; B $1: 1000$ mg; $B_{2}: 5000 \mathrm{mg}$; $B_{6}: 1500 \mathrm{mg}$; $B_{12}: 10 \mathrm{mg}$; Biotin: $50 \mathrm{mg}$; Coline chloride: $250000 \mathrm{mg}$; Pantothenic acid: $10000 \mathrm{mg}$; Nicotinic acid: $30000 \mathrm{mg}$; Folic acid: $1000 \mathrm{mg}$; Minerals: Mn: $60000 \mathrm{mg}$; Zn: $50000 \mathrm{mg}$; Fe: $30000 \mathrm{mg}$; Cu: $10000 \mathrm{mg}$;: $1000 \mathrm{mg}$; $\mathrm{Se}: 100 \mathrm{mg}$ and Co: $100 \mathrm{mg}$. 
Table (2). Effect of dietary treatments and housing systems on live body weight (LBW) and daily weight gain (DWG).

\begin{tabular}{|c|c|c|c|c|c|}
\hline \multirow{2}{*}{ Items } & \multirow{2}{*}{ Rearing (R) } & \multicolumn{3}{|c|}{ Dietary Energy Level (E) } & \multirow[t]{2}{*}{ Overall } \\
\hline & & Low & Medium & High & \\
\hline \multirow{3}{*}{$\begin{array}{l}\text { LBW } \\
\text { (at } 3 \text { weeks) }\end{array}$} & \multirow{3}{*}{$\begin{array}{c}\text { On floor pens } \\
\text { In Cages } \\
\text { Overall } \\
\end{array}$} & $690.01 \pm 2.21$ & $660.77 \pm 6.59$ & $658.85 \pm 10.21$ & 669.88 \\
\hline & & $670.41 \pm 35.06$ & $676.11 \pm 22.25$ & $631.52 \pm 36.10$ & 659.35 \\
\hline & & 680.22 & 668.44 & 645.19 & \\
\hline \multirow{3}{*}{$\begin{array}{l}\text { LBW } \\
\text { (at } 5 \text { weeks) }\end{array}$} & \multirow{3}{*}{$\begin{array}{c}\text { On floor pens } \\
\text { In Cages } \\
\text { Overall } \\
\end{array}$} & $1656.59 \pm 14.75$ & $1683.18 \pm 3.71$ & $1740.68 \pm 34.97$ & 1693.48 \\
\hline & & $1740.56 \pm 55.16$ & $1618.33 \pm 30.06$ & $1828.33 \pm 35.95$ & 1729.07 \\
\hline & & 1698.57 & 1650.76 & 1784.51 & \\
\hline \multirow{3}{*}{$\begin{array}{l}\text { DWG } \\
\text { (0-3 weeks) }\end{array}$} & \multirow{3}{*}{$\begin{array}{c}\text { On floor pens } \\
\text { In Cages } \\
\text { Overall }\end{array}$} & $30.68 \pm 0.13$ & $29.27 \pm 0.33$ & $29.12 \pm 0.48$ & 29.66 \\
\hline & & $29.72 \pm 1.71$ & $29.92 \pm 1.06$ & $27.87 \pm 1.72$ & 29.17 \\
\hline & & 30.16 & 29.59 & 28.49 & \\
\hline \multirow{3}{*}{$\begin{array}{l}\text { DWG } \\
\text { (4-5 weeks) }\end{array}$} & \multirow{3}{*}{$\begin{array}{l}\text { On floor pens } \\
\text { In Cages } \\
\text { Overall }\end{array}$} & $69.04 \pm 1.21$ & $67.99 \pm 1.32$ & $77.27 \pm 1.76$ & 71.43 \\
\hline & & $76.43 \pm 8.57$ & $67.30 \pm 10.87$ & $85.48 \pm 1.42$ & 76.40 \\
\hline & & $72.73^{\mathrm{ab}}$ & $67.64^{\mathrm{b}}$ & $81.38^{\mathrm{a}}$ & \\
\hline \multirow{3}{*}{$\begin{array}{l}\text { DWG } \\
(0-5 \text { weeks })\end{array}$} & \multirow{3}{*}{$\begin{array}{c}\text { On floor pens } \\
\text { In Cages } \\
\text { Overall } \\
\end{array}$} & $45.98 \pm 0.42$ & $44.76 \pm 0.72$ & \multirow{3}{*}{$\begin{array}{c}48.38 \pm 1.00 \\
50.91 \pm 1.04 \\
49.65\end{array}$} & 46.37 \\
\hline & & $48.40 \pm 4.46$ & $44.87 \pm 3.71$ & & 48.06 \\
\hline & & 47.19 & 44.81 & & \\
\hline \multicolumn{6}{|l|}{ Probability } \\
\hline Trait & \multicolumn{2}{|c|}{$\mathrm{R}$} & $\mathrm{E}$ & \multicolumn{2}{|c|}{$\mathrm{R} * \mathrm{E}$} \\
\hline LBW (0-3) & \multicolumn{2}{|c|}{ NS } & $\mathrm{NS}$ & \multicolumn{2}{|c|}{ NS } \\
\hline LBW (4-5) & \multicolumn{2}{|c|}{ NS } & NS & \multicolumn{2}{|c|}{ NS } \\
\hline DWG (0-3) & \multicolumn{2}{|c|}{ NS } & NS & \multicolumn{2}{|c|}{ NS } \\
\hline DWG (4-5) & \multicolumn{2}{|c|}{ NS } & NS & \multicolumn{2}{|c|}{ NS } \\
\hline DWG (0-5) & \multicolumn{2}{|c|}{ NS } & NS & \multicolumn{2}{|c|}{ NS } \\
\hline
\end{tabular}

Means within the same row or column with different superscripts are significantly different. NS = Non Significant

Table (3). Effect of dietary treatments and housing systems on daily feed intake (DFI) and feed conversion ratio (FCR).

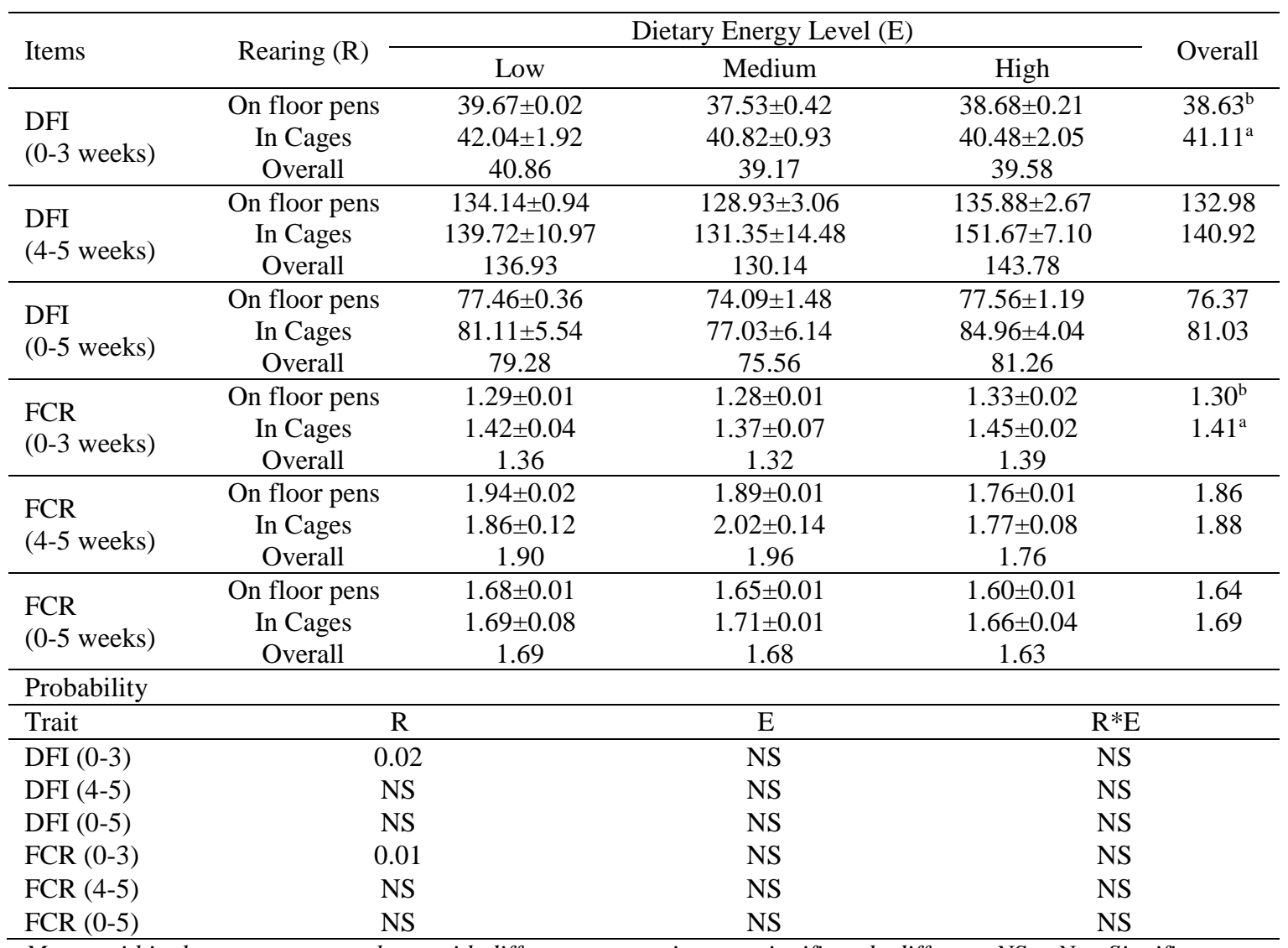

Means within the same row or column with different superscripts are significantly different. $N S=$ Non Significant 
Table (4). Effect of dietary treatments and housing systems on performance index (PI) and productive efficiency factor (PEF).

\begin{tabular}{|c|c|c|c|c|c|}
\hline \multirow[b]{2}{*}{ Items } & \multirow[b]{2}{*}{ Rearing (R) } & \multicolumn{3}{|c|}{ Dietary Energy Level (E) } & \multirow[b]{2}{*}{ Overall } \\
\hline & & Low & Medium & High & \\
\hline & On floor pens & $98.43 \pm 1.29$ & $97.40 \pm 1.12$ & $108.59 \pm 2.75$ & 101.47 \\
\hline $\begin{array}{l}\text { Performance } \\
\text { index }{ }^{1}\end{array}$ & $\begin{array}{c}\text { In Cages } \\
\text { Overall }\end{array}$ & $\begin{array}{c}104.71 \pm 3.60 \\
101.57\end{array}$ & $\begin{array}{c}81.87 \pm 1.08 \\
89.64\end{array}$ & $\begin{array}{c}109.13 \pm 3.67 \\
104.86\end{array}$ & 95.90 \\
\hline Production & On floor pens & $278.29 \pm 3.21$ & $281.23 \pm 3.69$ & $310.25 \pm 7.86$ & 289.92 \\
\hline $\begin{array}{l}\text { efficiency } \\
\text { factor }^{2}\end{array}$ & $\begin{array}{c}\text { In Cages } \\
\text { Overall }\end{array}$ & $\begin{array}{c}299.17 \pm 3.88 \\
290.20\end{array}$ & $\begin{array}{c}233.94 \pm 3.66 \\
256.12\end{array}$ & $\begin{array}{c}288.95 \pm 1.49 \\
299.60\end{array}$ & 274.02 \\
\hline \multicolumn{6}{|l|}{ Probability } \\
\hline Trait & $\mathrm{R}$ & & $\mathrm{E}$ & & \\
\hline $\mathrm{PI}^{1}$ & NS & & NS & & \\
\hline $\mathrm{PEF}^{2}$ & NS & & NS & & \\
\hline
\end{tabular}

Means within the same row or column with different superscripts are significantly different. $N S=$ Non Significant Sig. = Significance, $*(P \leq 0.05), N S=$ Non Significant. 1: North (1981), 2: Emmert (2000)

Table (5). Effect of dietary treatments on blood plasma parameters.

\begin{tabular}{|c|c|c|c|c|c|}
\hline \multirow{2}{*}{ Items } & \multirow{2}{*}{ Rearing (R) } & \multicolumn{3}{|c|}{ Dietary Energy Level (E) } & \multirow{2}{*}{ Overall } \\
\hline & & Low & Medium & High & \\
\hline \multirow{3}{*}{ Total protein mg/dl } & On floor pens & $8.62 \pm 0.65$ & $7.66 \pm 0.58$ & $4.88 \pm 0.67$ & 7.05 \\
\hline & In Cages & $7.40 \pm 1.34$ & $6.62 \pm 0.74$ & $7.25 \pm 1.85$ & 7.09 \\
\hline & Overall & 8.01 & 7.14 & 6.06 & \\
\hline \multirow{3}{*}{ Albumin mg/dl } & On floor pens & $3.07 \pm 0.77$ & $1.35 \pm 0.27$ & $1.63 \pm 0.41$ & $2.01^{\mathrm{b}}$ \\
\hline & In Cages & $3.16 \pm 0.75$ & $2.90 \pm 0.49$ & $3.05 \pm 0.63$ & $3.03^{\mathrm{a}}$ \\
\hline & Overall & 3.12 & 2.12 & 2.34 & \\
\hline \multirow{3}{*}{ Globulin mg/dl } & On Litter & $5.54 \pm 0.61$ & $6.31 \pm 0.50$ & $3.25 \pm 0.89$ & 5.03 \\
\hline & In Cages & $4.23 \pm 1.99$ & $3.72 \pm 0.90$ & $4.20 \pm 1.32$ & 4.05 \\
\hline & Overall & 4.89 & 5.02 & 3.72 & \\
\hline \multirow{3}{*}{$\begin{array}{l}\text { Albumin / } \\
\text { Globulin ratio }\end{array}$} & On floor pens & $0.60 \pm 0.18$ & $0.21 \pm 0.04$ & $0.76 \pm 0.34$ & 0.52 \\
\hline & In Cages & $1.65 \pm 0.84$ & $1.18 \pm 0.62$ & $0.79 \pm 0.14$ & 1.21 \\
\hline & Overall & 1.12 & 0.69 & 0.77 & \\
\hline \multirow{3}{*}{ Cholesterol mg/dl } & On floor pens & $157.56 \pm 17.82$ & $142.50 \pm 4.31$ & $144.88 \pm 30.76$ & 148.32 \\
\hline & In Cages & $145.25 \pm 31.17$ & $123.16 \pm 9.07$ & $166.97 \pm 25.83$ & 145.13 \\
\hline & Overall & 151.93 & 132.84 & 155.93 & \\
\hline \multirow{3}{*}{$\begin{array}{l}\text { Triglycerides } \\
\mathrm{mg} / \mathrm{dl}\end{array}$} & On floor pens & $153.99 \pm 14.97$ & $151.28 \pm 31.92$ & $137.01 \pm 22.41$ & 147.43 \\
\hline & In Cages & $183.85 \pm 17.75$ & $141.57 \pm 7.11$ & $108.14 \pm 12.98$ & 144.52 \\
\hline & Overall & 168.93 & 146.43 & 122.57 & \\
\hline \multicolumn{6}{|l|}{ Probability } \\
\hline Trait & \multicolumn{2}{|l|}{$\mathrm{R}$} & $\mathrm{E}$ & \multicolumn{2}{|c|}{$\mathrm{R} * \mathrm{E}$} \\
\hline Total protein & \multicolumn{2}{|l|}{ NS } & NS & \multicolumn{2}{|c|}{ NS } \\
\hline Albumin & \multicolumn{2}{|l|}{0.04} & NS & \multicolumn{2}{|c|}{ NS } \\
\hline Globulin & \multicolumn{2}{|l|}{ NS } & NS & \multicolumn{2}{|c|}{ NS } \\
\hline A / G ratio & \multicolumn{2}{|l|}{ NS } & NS & \multicolumn{2}{|c|}{ NS } \\
\hline Cholesterol & \multicolumn{2}{|l|}{ NS } & NS & \multicolumn{2}{|c|}{ NS } \\
\hline Triglycerides & \multicolumn{2}{|l|}{ NS } & NS & \multicolumn{2}{|c|}{ NS } \\
\hline
\end{tabular}


Table (6). Effect of dietary treatments and housing systems on carcass traits \&relative weight of lymphoid organs.

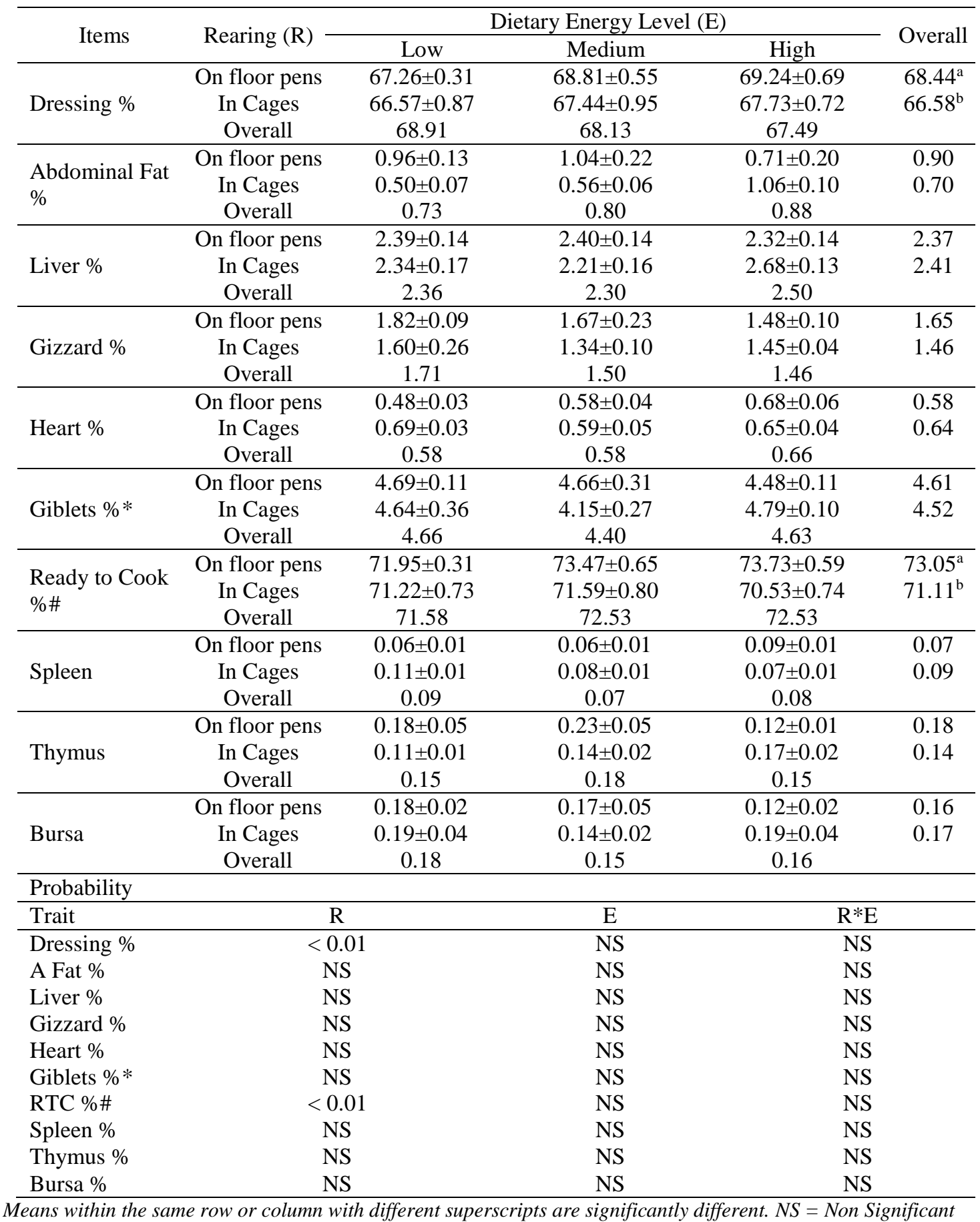


Table (7). Effect of three dietary treatments and two housing systems on economic traits.

\begin{tabular}{lcccccc}
\hline \multirow{2}{*}{ Items } & \multicolumn{5}{c}{ Dietary Treatments } \\
\cline { 2 - 6 } & \multicolumn{3}{c}{ On floor pens } & \multicolumn{3}{c}{ In Cages } \\
\cline { 2 - 6 } & Low & Medium & High & Low & Medium & High \\
\hline Average feed consumption & 2.71 & 2.59 & 2.71 & 2.84 & 2.69 & 2.97 \\
(Kg) & \pm 0.01 & \pm 0.05 & \pm 0.04 & \pm 0.19 & \pm 0.21 & \pm 0.14 \\
Total cost (LE) & 13.39 & 13.26 & 13.98 & 13.84 & 13.63 & 14.93 \\
& \pm 0.04 & \pm 0.18 & \pm 0.15 & \pm 0.67 & \pm 0.76 & \pm 0.52 \\
Feed cost (LE) & 9.39 & 9.26 & 9.98 & 9.84 & 9.63 & 10.93 \\
& \pm 0.04 & \pm 0.18 & \pm 0.15 & \pm 0.67 & \pm 0.76 & \pm 0.52 \\
Live body weight (Kg) & 1.65 & 1.61 & 1.74 & 1.74 & 1.62 & 1.83 \\
& \pm 0.01 & \pm 0.02 & \pm 0.03 & \pm 0.15 & \pm 0.12 & \pm 0.03 \\
Total return ${ }^{\#}$ (LE) & 24.02 & 23.38 & 25.24 & 25.23 & 23.47 & 26.51 \\
Net return (LE) & \pm 0.21 & \pm 0.36 & \pm 0.50 & \pm 2.25 & \pm 1.88 & \pm 0.52 \\
& 10.62 & 10.12 & 11.25 & 11.39 & 9.83 & 11.58 \\
Economic efficiency & \pm 0.16 & \pm 0.17 & \pm 0.35 & \pm 1.72 & \pm 1.12 & \pm 0.14 \\
Relative economic & 79.29 & 76.27 & 80.42 & 81.56 & 71.30 & 77.84 \\
efficiency & \pm 1.01 & \pm 0.28 & \pm 1.65 & \pm 1.85 & \pm 4.70 & \pm 2.89 \\
Mean economic efficiency & 100.00 & 96.20 & 101.43 & 102.86 & 89.93 & 98.16 \\
\hline
\end{tabular}

\# According to the local price (2013) of Kg LBW which was 13.00 L.E.

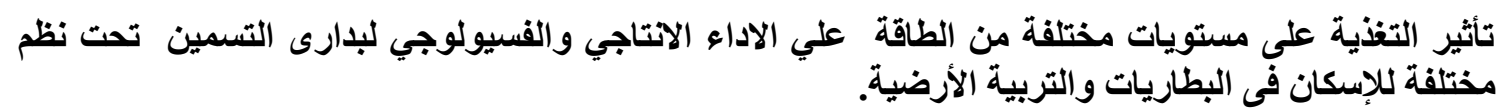

\author{
أحمد إبر اهيم سليمان1، نعمة الله جمال الدين محمد على1، رهام على محمد على2

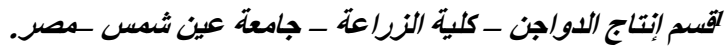 \\ مقسم الإتتاج الحيوانى والدواجن - كلية الزراعة والموارد الطبيعية - جامعة أسوان - مصر.
}

أجريت هذه التجربة لنقيبم ومقارنة استخدام ثلاثة مستويات مختلفة من الطاقة المثنلة فى علائق بدارى التسمين تحت نظامين للاسكان

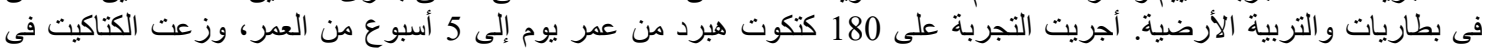

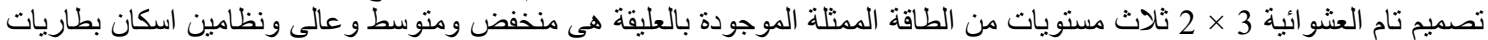
و التربية الأرضية. وزعت الكتة الكتاكيت على 6 معاملات بحيث تحتوى كل معاملة على 3 مكررات وكل مكرر على 10 كتاكيت.

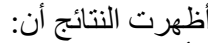

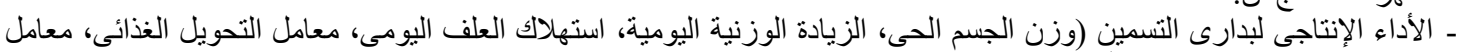

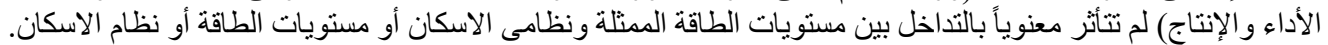

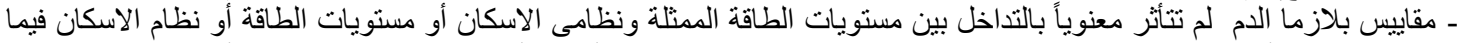

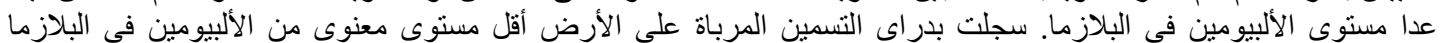

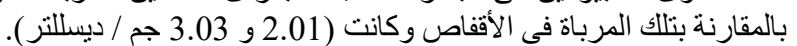

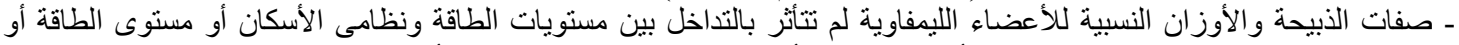

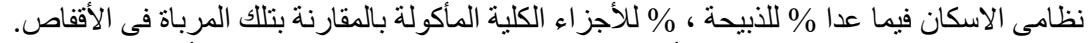

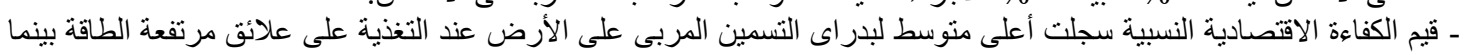

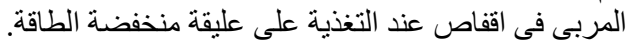
وتوصى الدراسة أن التربية الأرضية لبدارى التسمين تحسن معنوياً النسبة المئوية للانبيحة والنسبة المئوية للأجزاء الكلية الماكولة وكنلك متوسط الكفاءة الاقتصادية النسبية بالمقارنة بالتربية في أقفاص. 